\title{
Effect of Menstrual Cycle on Endurance Capacity of Obese Females in Andhra Pradesh
}

\author{
Chandana Bera ${ }^{1}$, Subarna Ghosh ${ }^{2}$ \\ 1,2 Department of Physiology, NC Medical College and Hospital, Israna, Panipat, Haryana, India.
}

\section{ABSTRACT}

\section{BACKGROUND}

Obesity is associated with irregular menstrual cycle in premenopausal women and both influence the endurance capacity due to fluctuation of fatigue and the negative effect of hormonal fluctuations during menstrual cycle. We wanted to investigate the effect of menstrual cycle on the cardiovascular response to exercise and on endurance capacity of obese females.

\section{METHODS}

75 sedentary healthy obese females of 18 to 20 years age group were selected on random basis as per the inclusion and exclusion criteria from the students of $1^{\text {st }}$ year B.Sc. MLT and B.Sc. Nursing Courses of Alluri Sitarama Raju Academy of Medical Sciences, Eluru, Andhra Pradesh. They were divided into Group - F, Group - L and Group - M containing 25 subjects in each group. All of them were asked to exercise in bicycle ergometer with $1 \mathrm{Kg}$ workload till exhaustion. Their resting heart rate, blood pressure before exercise and peak heart rate, recovery heart rate every minute up to $5^{\text {th }}$ minute, blood pressure after 5-minutes post rest were measured. The statistical analysis of the subject was done by SPSS (Statistical Package of Social Sciences), Version 16.0.

\section{RESULTS}

In this study, no significant variation $(\mathrm{p}>0.05)$ in the endurance capacity was seen during the follicular phase, but, endurance capacity is significantly $(p<0.001)$ reduced in menstrual phase compared to follicular and luteal phases.

\section{CONCLUSIONS}

In obese sedentary females, physical endurance is significantly reduced during the menstrual phase as compared to the other two phases of the menstrual cycle.

\section{KEY WORDS}

Obesity and Endurance, Menstrual Cycle and Endurance
Corresponding Author: Dr. Subarna Ghosh, 300/2, Acharya Prafulla Chandra Avenue, Dum Dum, Kolkata, West Bengal. Pin132107, India.

E-mail: gbubai@rocketmail.com

DOI: 10.14260/jemds/2020/795

How to Cite This Article:

Bera C, Ghosh S. Effect of menstrual cycle on endurance capacity of obese females in andhra pradesh. J Evolution Med Dent Sci 2020;9(48):3618-3623, $10.14260 /$ jemds/2020/795

Submission 24-08-2020,

Peer Review 17-10-2020,

Acceptance 24-10-2020,

Published 30-11-2020.

Copyright (C) 2020 Chandana Bera et al. This is an open access article distributed under Creative Commons Attribution License [Attribution 4.0 International (CC BY 4.0)] 


\section{BACKGROUND}

Endurance capacity is one's ability to do prolonged work before getting fatigued. Fatigue means tiredness. With repeated contraction, the muscle is becoming gradually weaker and this is the sign of fatigue. Muscle is a machine for converting the chemical energy to mechanical energy. The immediate source of chemical energy is from the breakdown of ATP (Adenosine Tri-Phosphate). 1 mole ATP can produce 7.3 Cal energy. The ultimate energy source is the intermediate metabolism of carbohydrates and lipids and the rate of it in skeletal muscle is low at rest. The energy sources in exercise also includes phosphocreatine, fatty acid, glycogen and lactic acid. The determining factors of endurance capacity include maximum $\mathrm{O}_{2}$ consumption, mitochondrial density, performance efficiency and body composition. However, sex differences exist but the basic underlying mechanism that determine performance are the same in the men and women. Maximum $\mathrm{O}_{2}$ consumption is largely determined by the cardiac output. The term "Obesity" refers to being over fat, and several methods for assessing fatness (skin fold, bio-electrical impedance, under weighing, and dual energy X-ray absorptiometry) are available. However, a more practical approach is to use Body Mass Index (BMI), which is recommended by the national institute of health to classify overweight and obesity and to estimate relative risk of disease. It is calculated as weight in kilogram divided by height in meters squared. BMI can also be estimated by using pounds and inches. ${ }^{1}$

\section{BMI $=$ Weight in Kg $/$ Height in $\mathrm{m}^{2}$}

Overweight is defined as having BMI 25 to $29.9 \mathrm{Kg} / \mathrm{m} 2$ and those with BMI greater than $30 \mathrm{Kg} / \mathrm{m} 2$ are considered obese. The National institute of Health Guidelines defined this population as adults with a BMI greater than $30 \mathrm{Kg} \cdot \mathrm{m}^{2}$ or those with greater than $25 \mathrm{Kg} . \mathrm{m}^{-2}$ with a family history of obesity. ${ }^{2}$ The specific health risk caused by obesity includes impaired cardiac function as a result of increased mechanical work and autonomic and left ventricular dysfunction, hypertension and stroke.3,4,5,6, Obesity also causes adult onset of diabetes, as about $80 \%$ of these patients are overweight.7,8,9,10 The renal disease, pulmonary disease and impaired function resulting from the added effort needed to move the chest wall, problems in administering anaesthetics during surgery, osteoarthritis, degenerative joint disease, and gout, sever types of cancer, abnormal plasma lipid and lipoprotein levels, menstrual health problems i.e. obese woman suffer more menstrual disorders, e.g. the frequency of menstrual disturbance in women with morbid obesity (BMI $40+$ ) is three times greater than for woman of normal weight.11,12,13,14 Obesity in premenopausal women is associated with irregular menstrual cycle and infertility.

In humans and other primates, in the menstrual cycle the most conspicuous feature is the periodic vaginal bleeding that occurs with the shedding of uterine mucosa (menstruation). The length of the cycle is variable in woman, but an average figure is 28 days from the start of one menstrual period to the start of the next. By common usage the days of cycle are identified by number starting with the first day of menstruation. ${ }^{15}$ The variation in different hormonal levels occurs in menstrual cycle. Among them LH (Luteinizing Harmone), estradiol and progesterone levels are influenced by exercise.

\section{METHODS}

In this study, the ethical considerations were taken into account. Before an individual becomes a subject of this study, she shall be notified of the aims, methods, anticipated benefits and potential hazards of the study. Her right to abstain from participation in the study and her right to terminate at any time along with confidential nature of her replies were also explained. No individual were taken as a subject of this study unless she provides a freely given consent that she agrees to participate. No pressure or inducement of any kind was applied to encourage an individual to become a subject of this study. No information revealing the identity or communication of any subject was included in the final report. This experiment was conducted in the research laboratory of the Department of Physiology, Alluri Sitarama Raju Academy of Medical Sciences (ASRAMS), Eluru between 8 am. to 9 am. 75 healthy sedentary female subjects of 18 to 20 years age group, who were having the Waist Hip Ratio (WHR) $>0.80$ and Basal Metabolic Index (BMI) > 30, were selected randomly from the students of $1^{\text {st }}$ year B.Sc. MLT and B.Sc. Nursing Courses of ASRAMS. The subjects belong to comparable socioeconomic status and were eating in the same hostel mess. They continued their usual activity throughout the period of the experimental procedure. They were familiarized with the bicycle ergometer for 1 - 2 days to allay their apprehension and nervousness during the actual procedure.

\section{Exclusion Criteria}

Subjects suffering from any menstrual irregularities, painful menstruation and any cardiorespiratory disorder or any upper or lower motor neuron disorder or any major illness or brain disease, subjects taking any kind of drugs etc.

\section{Inclusion Criteria}

Healthy, non-smoker, with no cardiorespiratory disorders. Subject not doing any type of physical exercise.

\section{Sample Size}

75 female students were randomly divided into 3 groupsGroup F = 25 students in follicular phase

Group $\mathrm{L}=25$ students in luteal phase

Group $\mathrm{M}=25$ students in menstrual phase

\section{Apparatus Required}

Bicycle ergometer, Weighing Machine (Kg), Height Measuring Scale $(\mathrm{cm})$, Sphygmomanometer $(\mathrm{mmHg})$ and Stethoscope, Measuring Tape (inch), Electronic Stopwatch (seconds and milliseconds). 
Determination of Anthropometric Parameters Before the starting the study, the physical parameters i.e. height in $\mathrm{cm}$ and weight in $\mathrm{Kg}$ of the selected subjects were noted down (without shoes) by using the height measuring scale and weighing machine. The waist circumference (between the costal margin and iliac crest) and hip circumference (over the buttocks) were measured in $\mathrm{cm}$ by using measuring tape. The WHR was calculated.

After measuring the parameters, the subjects were allowed to take rest for $15-20$ minutes in recumbent position on the couch. The experimental protocol was explained to them before test and the written consent was obtained.

After relaxation, the pre-exercise heart rate in beats / minute was noted down by using electronic stop watch and blood pressure (mmHg) was noted down by using stethoscope and sphygmomanometer.

Subjects were allowed to do cycling with $1 \mathrm{Kg}$ workload at a frequency of 30 cycles / minute in the bicycle ergometer till exhaustion. At the moment of starting, the time was noted down. They were considered as fatigued when they were unable to continue the exercise with the frequency of 30 cycles / minute. The duration of exercise was noted down at the moment of cessation of exercise. After getting exhausted they were instructed to stop exercise and the time duration of exercise was recorded in minutes. The duration of exercise till onset of fatigue was considered as the endurance capacity.

After cessation of exercise immediately peak heart rate was recorded by feeling carotid pulsation for $15 \mathrm{sec}$ period by using electronic stopwatch. After that the recovery heart rates were noted down by feeling carotid pulsation for $15 \mathrm{sec}$ period in each minute by using electronic stopwatch up to $5^{\text {th }}$ minute. 5 minutes after the cessation of exercise arterial blood pressure was noted down.

\section{Study Design}

The subjects were asked to come to the research laboratory in Department of Physiology at 8 am sharp. The entire experiment was done in 03 days, one day for each group. After coming to lab, the anthropometric parameters of the subjects were measured. Then the subjects were allowed to take rest for 15 - 20 minutes. After relaxation, the resting heart rate and blood pressure were measured. Then the subjects were allowed to do cycling bicycle ergometer with $1 \mathrm{Kg}$ workload, till exhaustion. After exercise the peak heart rate, recovery heart rate and post exercise blood pressure were measured.

\section{Statistical Analysis}

The statistical analysis of the subject was done by SPSS (Statistical Package of Social Sciences), Version 16.0, designed by the TISS (Tata Institute of Social Studies).

\section{RESULTS}

In this study on obese subjects, no significant variation ( $\mathrm{p}>$ 0.05 ) in the endurance capacity was seen during the follicular phase, but, endurance capacity is significantly ( $p<0.001$ ) reduced in menstrual phase compare to other two phases (Table 1). No significant variation ( $p>0.05)$ was also observed in the resting heart rate during the follicular phase and luteal phase of the menstrual cycle. But the resting heart rate is significantly $(\mathrm{p}<0.001)$ high in menstrual phase compare to other phases (Table 2). There was also no significant difference $(p>0.05)$ in the peak heart rate in 3 different phases of the menstrual cycle in (Table 2). No significant variation ( $p$ $>0.05$ ) in the recovery heart rate is seen during the follicular phase and luteal phase of the menstrual cycle but recovery heart rate is significantly $(\mathrm{p}<0.001)$ slower in menstrual phase compare to other two phases (Table 2).

\begin{tabular}{|ccccccc|}
\hline $\begin{array}{c}\text { Variation of Endurance Capacity } \\
\text { (minute) during Menstrual } \\
\text { Cycle }\end{array}$ & $\begin{array}{c}\text { Compared } \\
\text { Groups }\end{array}$ & P-Value & Inference \\
Phase & $\begin{array}{c}\text { Mean } \\
\text { SD }\end{array}$ & SE & & & \\
ECF & 9.587 & 0.994 & 0.198 & ECF vs. ECL & 0.453 & Not Significant \\
ECL & 9.654 & 0.906 & 0.181 & ECL vs. ECM & 0.0001 & Highly Significant \\
ECM & 7.879 & 0.950 & 0.190 & ECM vs. ECF & 0.0001 & Highly Significant \\
\hline Table 1. Comparison of Endurance Capacity in 3 Different Phases of \\
Menstrual Cycle within the Obese Group
\end{tabular}

\begin{tabular}{|c|c|c|c|c|c|c|c|}
\hline $\begin{array}{l}\text { Heart } \\
\text { Rate } \\
\text { Profile }\end{array}$ & $\begin{array}{r}\text { Varia } \\
\text { Rat } \\
\text { dur }\end{array}$ & $\begin{array}{l}\text { tion of } \\
\text { te (Bea } \\
\text { ing Mer }\end{array}$ & $\begin{array}{l}\text { Resting } \\
\text { S / Min } \\
\text { strual }\end{array}$ & $\begin{array}{l}\text { Heart } \\
\text { te) } \\
\text { ycle }\end{array}$ & $\begin{array}{c}\text { Compared } \\
\text { Groups }\end{array}$ & $\mathbf{P}$ & Inference \\
\hline \multirow{4}{*}{$\begin{array}{c}\text { Resting } \\
\text { Heart } \\
\text { Rate }\end{array}$} & HR & Mean & SD & SE & & & \\
\hline & RHRF & 78.64 & 3.251 & 0.650 & RHRF vs. RHRL & 0.472 & $\begin{array}{c}\text { Not } \\
\text { Significant }\end{array}$ \\
\hline & RHRL & 79.28 & 3.048 & 0.610 & RHRL vs. RHRM & 0.0001 & $\begin{array}{c}\text { Highly } \\
\text { Significant }\end{array}$ \\
\hline & RHRM & 83.68 & 3.092 & 0.618 & RHRM vs. RHRF & 0.0001 & $\begin{array}{c}\text { Highly } \\
\text { Significant }\end{array}$ \\
\hline \multirow{3}{*}{$\begin{array}{c}\text { Peak } \\
\text { Heart } \\
\text { Rate } \\
\text { Profile }\end{array}$} & PHRF & 167.67 & 5.981 & 1.196 & PHRF vs. PHRL & 0.722 & $\begin{array}{c}\text { Not } \\
\text { Significant }\end{array}$ \\
\hline & PHRL & 168.32 & 5.406 & 1.081 & PHRL vs. PHRM & 0.417 & $\begin{array}{c}\text { Not } \\
\text { Significant }\end{array}$ \\
\hline & PHRM & 169.60 & 5.228 & 1.046 & PHRM vs. PHRF & 0.245 & $\begin{array}{c}\text { Not } \\
\text { Significant }\end{array}$ \\
\hline \multirow{15}{*}{\begin{tabular}{|c|} 
Recovery \\
Heart \\
Rate \\
Profile
\end{tabular}} & $\mathrm{rHR}_{1} \mathrm{~F}$ & 148.80 & 7.094 & 1.419 & $\mathrm{rHR}_{1} \mathrm{~F}$ vs. $\mathrm{rHR}_{1} \mathrm{~L}$ & 0.965 & $\begin{array}{c}\text { Not } \\
\text { Significant }\end{array}$ \\
\hline & $\mathrm{rHR}_{1} \mathrm{~L}$ & 148.88 & 6.326 & 1.252 & $\mathrm{rHR}_{1} \mathrm{~L}$ vs. $\mathrm{rHR}_{1} \mathrm{M}$ & 0.0001 & $\begin{array}{c}\text { Highly } \\
\text { Significant }\end{array}$ \\
\hline & $\mathrm{rHR}_{1} \mathrm{M}$ & 159.92 & 5.930 & 1.186 & $\mathrm{rHR}_{1} \mathrm{M}$ vs. $r \mathrm{rR}_{1} \mathrm{~F}$ & 0.0001 & $\begin{array}{c}\text { Highly } \\
\text { Significant }\end{array}$ \\
\hline & $\mathrm{rHR}_{2} \mathrm{~F}$ & 127.04 & 7.530 & 1.506 & $\mathrm{rHR}_{2} \mathrm{~F}$ vs. $\mathrm{rHR}_{2} \mathrm{~L}$ & 0.801 & $\begin{array}{c}\text { Not } \\
\text { Significant }\end{array}$ \\
\hline & $\mathrm{rHR}_{2} \mathrm{~L}$ & 127.52 & 6.252 & 1.250 & $\mathrm{rHR}_{2} \mathrm{~L}$ vs. $\mathrm{Rhr}_{2} \mathrm{M}$ & 0.0001 & $\begin{array}{c}\text { Highly } \\
\text { Significant }\end{array}$ \\
\hline & $\mathrm{rHR}_{2} \mathrm{M}$ & 138.88 & 4.936 & 0.987 & $\mathrm{rHR}_{2} \mathrm{M}$ vs. $\mathrm{rHR}_{2} \mathrm{~F}$ & 0.0001 & $\begin{array}{c}\text { Highly } \\
\text { Significant }\end{array}$ \\
\hline & $\mathrm{rHR}_{3} \mathrm{~F}$ & 109.68 & 6.073 & 1.215 & $\mathrm{rHR}_{3} \mathrm{~F}$ vs. $\mathrm{rHR}_{3} \mathrm{~L}$ & 0.844 & $\begin{array}{c}\text { Not } \\
\text { Significant }\end{array}$ \\
\hline & $\mathrm{rHR}_{3} \mathrm{~L}$ & 110.00 & 5.567 & 1.114 & $\mathrm{rHR}_{3} \mathrm{~L}$ vs. $\mathrm{rHR}_{3} \mathrm{M}$ & 0.0001 & $\begin{array}{c}\text { Highly } \\
\text { Significant }\end{array}$ \\
\hline & $\mathrm{rHR}_{3} \mathrm{M}$ & 120.32 & 5.406 & 1.081 & $\mathrm{rHR}_{3} \mathrm{M}$ vs. $\mathrm{rHR}_{3} \mathrm{~F}$ & 0.0001 & $\begin{array}{c}\text { Highly } \\
\text { Significant }\end{array}$ \\
\hline & $\mathrm{rHR}_{4} \mathrm{~F}$ & 96.96 & 4.363 & 0.873 & $\mathrm{rHR}_{4} \mathrm{~F}$ vs. $\mathrm{rHR}_{4} \mathrm{~L}$ & 0.755 & $\begin{array}{c}\text { Not } \\
\text { Significant }\end{array}$ \\
\hline & $\mathrm{rHR}_{4} \mathrm{~L}$ & 97.37 & 3.988 & 0.798 & $\mathrm{rHR}_{4} \mathrm{~L}$ vs. $\mathrm{rHR}_{4} \mathrm{M}$ & 0.0001 & $\begin{array}{c}\text { Highly } \\
\text { Significant }\end{array}$ \\
\hline & $\mathrm{rHR}_{4} \mathrm{M}$ & 105.12 & 5.102 & 1.020 & $\mathrm{rHR}_{4} \mathrm{M}$ vs. $\mathrm{rHR}_{4} \mathrm{~F}$ & 0.0001 & $\begin{array}{c}\text { Highly } \\
\text { Significant }\end{array}$ \\
\hline & $\mathrm{rHR}_{5} \mathrm{~F}$ & 84.04 & 4.800 & 0.960 & $\mathrm{rHR}_{5} \mathrm{~F}$ vs. $\mathrm{rHR}_{5} \mathrm{~L}$ & 0.678 & $\begin{array}{c}\text { Not } \\
\text { Significant }\end{array}$ \\
\hline & $\mathrm{rHR}_{5} \mathrm{~L}$ & 84.48 & 2.993 & 0.705 & rHR $_{5} \mathrm{~L}$ vs. $\mathrm{rHR}_{5} \mathrm{~F}$ & 0.0001 & $\begin{array}{c}\text { Highly } \\
\text { Significant }\end{array}$ \\
\hline & $\mathrm{rHR}_{5} \mathrm{M}$ & 93.84 & 5.684 & 1.137 & $\mathrm{rHR}_{5} \mathrm{M}$ vs. $\mathrm{rHR}_{5} \mathrm{~F}$ & 0.0001 & $\begin{array}{c}\text { Highly } \\
\text { Significant }\end{array}$ \\
\hline
\end{tabular}

In this study we also found that the post exercise SBP is also significantly $(\mathrm{p}<0.05)$ higher in the obese females, in all 3 phases of the menstrual cycle. Before exercise, no significant difference ( $p>0.05$ ) was seen in SBP (Systolic Blood Pressure) and DBP (Diastolic Blood Pressure), during the different phases of the menstrual cycle in both obese groups (Table 3). 
After exercise, no significant difference ( $p>0.05$ ) was seen in SBP and DBP, during the different phases of the menstrual cycle in obese groups (Table 3 ).

\begin{tabular}{|c|c|c|c|c|c|c|c|}
\hline Exercise & $\begin{array}{l}\text { Blood P } \\
\text { Phases }\end{array}$ & $\begin{array}{l}\text { ressure } \\
\text { of Men }\end{array}$ & $\begin{array}{l}\text { e in Dif } \\
\text { istrual }\end{array}$ & $\begin{array}{l}\text { ferent } \\
\text { Cycle }\end{array}$ & Compared & $\mathbf{P}$ & \\
\hline & BP & Mean & SD & SE & & Value & Inte \\
\hline & $\mathrm{B}_{\mathrm{X}} \mathrm{SBPF}$ & 124.64 & 3.252 & 0.650 & $\mathrm{~B}_{\mathrm{X}} \mathrm{SBPF}$ vs $\mathrm{B}_{\mathrm{X}} \mathrm{SBPL}$ & 0.896 & $\begin{array}{c}\text { Not } \\
\text { Significant }\end{array}$ \\
\hline & $\mathrm{B}_{\mathrm{X}} \mathrm{SBPL}$ & 124.72 & 2.993 & 0.599 & $\mathrm{~B}_{\mathrm{X}} \mathrm{SBPL}$ vs $\mathrm{B}_{\mathrm{X}} \mathrm{SBPM}$ & 0.786 & $\begin{array}{c}\text { Not } \\
\text { Significant }\end{array}$ \\
\hline $\begin{array}{l}\text { Before } \\
\text { Exercise }\end{array}$ & $\mathrm{B}_{\mathrm{X}} \mathrm{SBPM}$ & 124.88 & 3.166 & 0.633 & $\mathrm{~B}_{\mathrm{X}} \mathrm{SBPM}$ vs $\mathrm{B}_{\mathrm{X}} \mathrm{SBPF}$ & 0.986 & $\begin{array}{c}\text { Not } \\
\text { Significant }\end{array}$ \\
\hline & BxDBPF & 83.520 & 2.600 & 0.520 & BxDBPF vs BxDBPL & 0.903 & $\begin{array}{c}\text { Not } \\
\text { Significant }\end{array}$ \\
\hline & BxDBPL & 83.440 & 2.200 & 0.440 & $\begin{array}{c}\text { B }_{\mathrm{x}} \mathrm{DBPL} \text { vs } \\
\text { BxDBPM }\end{array}$ & 1.000 & $\begin{array}{c}\text { Not } \\
\text { Significant }\end{array}$ \\
\hline & BxDBPM & 83.442 & 3.166 & 0.633 & $\begin{array}{c}\text { BxDBPM vs } \\
\text { BxDBPF }\end{array}$ & 0.908 & $\begin{array}{c}\text { Not } \\
\text { Significant }\end{array}$ \\
\hline & $\mathrm{A}_{\mathrm{X}} \mathrm{SBPF}$ & 144.80 & 3.215 & 0.643 & $A_{x} S B P F$ vs $A_{x} S B P L$ & 0.928 & $\begin{array}{c}\text { Not } \\
\text { Significant }\end{array}$ \\
\hline & $\mathrm{A}_{X} \mathrm{SBPL}$ & 144.72 & 3.311 & 0.662 & $\mathrm{~A}_{\mathrm{X}} \mathrm{SBPL}$ vs $\mathrm{A}_{\mathrm{X}} \mathrm{SBPM}$ & 0.857 & $\begin{array}{c}\text { Not } \\
\text { Significant }\end{array}$ \\
\hline After & $\mathrm{A}_{\mathrm{X}} \mathrm{SBPM}$ & 144.56 & 2.859 & 0.572 & $A_{x} S B P M$ vs $A_{x} S B P F$ & 0.787 & $\begin{array}{c}\text { Not } \\
\text { Significant }\end{array}$ \\
\hline Exercise & $\mathrm{A}_{\mathrm{x}} \mathrm{DBPF}$ & 80.96 & 2.389 & 0.478 & $\mathrm{~A}_{\mathrm{X}} \mathrm{DBPF}$ vs $\mathrm{A}_{\mathrm{X}} \mathrm{DBPL}$ & 0.894 & $\begin{array}{c}\text { Not } \\
\text { Significant }\end{array}$ \\
\hline & $\mathrm{A}_{\mathrm{X}} \mathrm{DBPL}$ & 80.88 & 1.922 & 0.384 & $\begin{array}{c}A_{x} \text { DBPL vs } \\
A_{x} \text { DBPM }\end{array}$ & 0.790 & $\begin{array}{c}\text { Not } \\
\text { Significant }\end{array}$ \\
\hline & $A_{x} D B P M$ & 81.04 & 2.010 & 0.402 & $\begin{array}{c}A_{x} \text { DBPM vs } \\
A_{x} \text { DBPF }\end{array}$ & 0.892 & $\begin{array}{c}\text { Not } \\
\text { Significant }\end{array}$ \\
\hline
\end{tabular}

\section{DISCUSSION}

Endurance capacity was significantly lower at the menstrual phase compared to other two phases of the menstrual cycle in the obese females. Different scientists had investigated the influence of the menstrual cycle on exercise and cardiovascular responses. Most of them concluded from their findings that exercise capacity was reduced during the menstrual phase. ${ }^{17,18,19,20,21,22,23,24,25}$

Endurance capacity will be more in the individuals whose resting heart rate is less. ${ }^{26,27,28}$ While discussing the endurance capacity we should correlate it with the cardiovascular parameter that is resting, peak and recovery heart rate. The resting heart rate of any individual is determined by the parasympathetic tone (vagal tone). At any moment due to physiological cause or pathological cause, if the sympathetic tone is increased, the resting heart rate is also increased. Obesity causes increase in sympathetic tone and causes increase of resting heart rate. ${ }^{29,30,31}$ In the obese, insulin stimulated glucose uptake in the skeletal muscle decreases, that causes early muscular fatigue. ${ }^{32}$ Both the lactate accumulation and decreased glucose uptake by muscles reduce the endurance capacity in the obese females.

In the obese it is observed, especially in menstrual phase, physical discomfort might be the cause of more sympathetic tone causing a higher resting heart rate. The peak heart rates did not vary significantly in the three phases of menstrual cycle in our obese subjects. The increase in heart rate occurs as soon as exercise begins or may be seen even before the exercise begins (anticipatory tachycardia).

The heart rate increases at the time of exercise due to:

a. Sympathetic discharge that originates centrally, whenever there is an increase in motor activity and is responsible for tachycardia. Even the thought of exercise stimulates the hypothalamic defence area, bringing about increase sympathetic discharge and causing the anticipatory tachycardia. ${ }^{28}$ When the noradrenergic sympathetic fibres to the nodal tissues are stimulated, it causes the release of nor-epinephrine from the nerve endings that will bind to the $\beta_{1}$-adrenergic receptor. It in turn will cause the increasing of intracellular concentration of cAMP and facilitates the opening of long lasting $\mathrm{Ca}^{2+}$ channels. ${ }^{8}$ Thus, there will be an increase in steepness of phase-4 (pacemaker potential) of action potential of pacemaker tissue, which will increase the heart rate.

b. Peripheral reflexes, originating from exercising muscle (muscle spindles, muscle-tendon receptors) and joints are responsible for the increase in heart rate which occurs as soon as exercise begins.

c. Local metabolic factors, contributes to the sustained increase in heart rate during prolonged exercise. Muscle tissues have nociceptor (free nerve ending) which is stimulated by lactic acid, potassium ions and other metabolites which collect in exercising muscle. Thus, the increased heart rate can also be explained as an effect of increase collection of lactic acid.

d. Adrenaline, noradrenaline from the sympathetic nerve endings and thyroid hormones during exercise also contribute to the increase in heart rate during sustained exercise. ${ }^{28}$

e. Intrinsic factors increase the heart rate during exercise by stimulating the SA (Sino-Atrial) node in the right atrium through increasing the venous return and Bainbridge reflex.

f. Increased activity of the heart during exercise increases the myocardial temperature, which in turn stimulates the SA Node of the heart and causes increase in its rhythmicity.

The heart rate starts decreasing after cessation of exercise (recovery heart rate) but takes considerable time to achieve resting level. This is likely due to the effect of persisting local metabolites, hormonal factors and increased temperature. Gradually the resting sympathetic tone is established. In our obese subjects, the recovery of normal heart rate was significantly slower in the menstrual period, due to higher sympathetic discharge.

In our obese subjects, pre-exercise systolic blood pressure in different phases of menstrual cycle did not varies significantly, but after exercise, SBP significantly increases in all phases with insignificant inter phase variation. The diastolic blood pressure was not significantly different in our subjects in the three phases of menstrual cycle both before and after exercise, but after exercise, DBP was little lower than before exercise in all phases of menstrual cycle. SBP is always raised by exercise since it depends upon the cardiac output which increases in exercise. The SBP remains elevated during the exercise and is not reflexly corrected by baroreceptor reflex, because, numerous descending tracts from hypothalamic defence centre inhibit the baroreceptor afferents. DBP primarily depends upon the peripheral resistance that may decrease or remain unchanged during exercise. Mostly the vasodilatation in the skeletal muscle 
balances the vasoconstriction in other tissues, so DBP is not changed much

\section{CONCLUSIONS}

From this study it is concluded that in obese sedentary females, physical endurance is significantly reduced during the menstrual phase as compared to the other two phases of the menstrual cycle. The resting heart rate was significantly higher in the menstrual phase than the other two phases. The recovery heart rate was significantly slower in menstrual phase. But the menstruation had no influence on post exercise SBP and DBP.

Data sharing statement provided by the authors is available with the full text of this article at jemds.com.

Financial or other competing interests: None.

Disclosure forms provided by the authors are available with the full text of this article at jemds.com.

\section{REFERENCES}

[1] Brooks GA, Fahey TD. Exercise physiology. Chap- 5. John Wiley and Sons 1984.

[2] Blackbrun GL, Wilson GT, Kanders BS, et al. Weight cycling: the experience of human dieters: Am J Clin Nutr 1989;49(5 Suppl):1105-9.

[3] Rossi M, Marti G, Ricordi L, et al. Cardiac autonomic disfunction in obese subjects. Clin Sci (Lond) 1989;76(6):567-72.

[4] Stamler R, Stamler J, Riedlinger WF, et al. Weight and blood pressure. Findings in hypertension, screening of 1 million Americans. JAMA 1978;240(15):1607-10.

[5] Pi-Sunyer FX. Obesity. In: Shils ME, Olson JA, Shike M, eds. Modern nutrition in health and disease. Philadelphia: Lea and Febiger 1994.

[6] Stern JS, Johnson PR, Batchelor BR, et al. Pancreatic insulin release and peripheral tissue resistance in Zucker obese rats fed high and low carbohydrate diets. Am J Physiol 1975;228(2):543-8.

[7] Weisinger JR, Kempson RL, Eldridge FL, et al. The nephritic syndrome: a complication of massive obesity. Ann Intern Med 1974;81(4):440-7.

[8] Barrett KE, Barman SM, Boitano S, et al. The gonads: development and function of the reproductive system. Chap- 25. In: Ganong's review of medical physiology. 23 rd edn. New Delhi: Tata McGraw Hill Education Pvt. Ltd. 2010:412-3.

[9] Warner WA, Garrett LP. The obese patient and anesthesia. JAMA 1968;205(2):102-3.

[10] Felson DT. Weight loss reduces the risk for symptomatic Knee osteoarthritis in women: the Framingham Study. Ann Intern Med 1992;116(7):535-9.

[11] Welle SL, Seaton TB, Campbell RG. Some metabolic effects of overeating in man. Am J Clin Nutr 1986;44(6):718-24.

[12] Rossner S, Hallberg D. Serum lipoproteins in massive obesity. A study and after jejunoileal shunt operation. Acta Med Scand 1978;204(1-2):103-10.
[13] Friedmann B, Kindermann W. Energy metabolism and regulatory hormones in women and men during continuous exercise. Eur J Appl Physiol 1989;59(1-2):1-9.

[14] Norman RJ, Clark AM. Obesity and reproductive disorders: a review. Report Fertil Dev 1998;10(1):55-63.

[15] Barrett KE, Barman SM, Boitano S, et al. The gonads: Development and function of the reproductive system. Chap- 25. In: Ganong's review of medical physiology. 22 ${ }^{\text {nd }}$ edn. New Delhi: Tata McGraw Hill Education Pvt Ltd 2005:391-411.

[16] Du Bois D, Du Bois EF. Clinical calorimetry: tenth paper a formula to estimate the approximate surface area if height and weight be known. Arch Intern Med 1916;17(62):863-71.

[17] Jurkowski JE, Jones NL, Towes CJ, et al. Effect of menstrual cycle on blood lactate, 02 delivery and performance during exercise. J Appl Physiol Respir Environ Exerc Physiol 1981;51(6):1493-9.

[18] Stephenson LA, Kolka MA, Wilkerson JE. Metabolic and thermoregulatory responses to exercise during the human menstrual cycle. Med Sci Sports Exerc 1982;14(4):270-5.

[19] Chatterjee P, Nag S, Kali M, et al. Effect of physical exercise in three different phases of menstrual cycle on nonathletic women. Biomedicine 1986;6(1):15-8.

[20] De Souza MJ, Maguire MS, Rubin KR, et al. Effect of menstrual phase and amenorrhea on exercise performance in runners. Med Sci Sports Exerc 1990;22(5):575-80.

[21] Sarkar S, Nag S, Chatterjee P. Menstrual cycle - its effect on some cardio-respiratory responses to exercise. Biomedicine 1996;16(2 \& 3):33-40.

[22] Friden C, Hirschberg AL, Saartok T. Muscle strength and endurance do not significantly vary across 3 phases of menstrual cycle in moderately active premenopausal women. Clin J Sport Med 2003;13(4):238-41.

[23] Bushman B, Masterson G, Nelsen J. Anaerobic power performance and the menstrual cycle: eumenorrheic and oral contraceptive users. Journal of Sports Medicine and Physical Fitness 2006;46(1):132-7.

[24] Smekal G, von Duvillard SP, Frigo P, et al. Menstrual cycle: no effect on exercise cardiorespiratory variables or blood lactate concentration. Med Sci Sports Exerc 2007;39(7):1098-106.

[25] Tsampoukos A, Peckham EA, James R, et al. Effect of menstrual cycle phase on sprinting performance. Eur J Appl Physiol 2010;109(4):659-67.

[26] de Jonge XAJ, Boot CR, Thom JM, et al. The influence of menstrual cycle phase on skeletal muscle contractile characteristics in humans. J Physiol 2001;530(Pt 1):1616.

[27] Brukner P, Khan K. Clinical sports medicine. $3^{\text {rd }}$ edn. Tata McGrawHill Publishing Company Limited 2008:752-8.

[28] McArdle WD, Katch VL, Katch FI. Exercise physiology: energy nutrition and human performance. $4^{\text {th }}$ edn. Lea and Febiger 1996.

[29] Flier JS, Flier EM. Biology of obesity. In: Fauci A, Braunwald E, Kasper D, et al, eds. Harrison's principles of internal medicine. Vol. 1. 17th edn. McGraw Hill Education 2008:467-8. 
[30] Shigetoh Y, Adachi H, Yamagishi S, et al. Higher heart rate may predispose to obesity and diabetes mellitus: 20-year prospective study in a general population. Am J Hypertens 2009;22(2):151-5.

[31] Novak CM, Escande C, Gerber SM, et al. Endurance capacity, not body size, determines physical activity levels: role of skeletal muscle PEPCK. PloS One 2009;4(6):e5869.

[32] van der Graaf M, de Haan JH, Smits P, et al. The effect of acute exercise on glycogen synthesis rate in obese subjects studied by $13^{\mathrm{C}}$ MRS. Eur J Appl Physiol 2011;111(2):275-83. 